\title{
Healthcare Expenditure Efficiency Analysis Regarding to Healthcare Access in 34 Provinces in Indonesia
}

\author{
Jeffrey Aron Natan \\ Corresponding Author, aron.jeffrey@yahoo.com, 087825775512 \\ Department of Economics, Faculty of Economics and Business, Universitas Padjadjaran
}

\begin{abstract}
According to World Health Organization (WHO) office for Indonesia, in 2015, Indonesia's general government expenditure on health as \% of GDP became one of the lowest in the world with 1,5\% $(\mathrm{Rp} 21,1 \mathrm{~T})$. This number depicts the fact that Indonesia's HDI is only 0.689, positioning it at 113 out of 188 countries and territories. Nevertheless low HDI score in Indonesia is caused by inefficiency in healthcare expenditure. This is the main focus of this paper.
\end{abstract}

This paper has two main objectives, primarily comparison between all provinces in Indonesia, we estimate technical efficiency of expenditure on healthcare. Second, is to analyze the factors that create inequality of healthcare access in Indonesia. We calculated technical efficiency in healthcare expenditure by using Data Envelopment Analysis (DEA) among 34 provinces in Indonesia in 2015. The DEA method uses 2 inputs, the realization of health deconcentration funds and realization of healthcare assistance, and the outputs are medication of malnutrition case, childbirth assisted by health personnel, treated diarrhea by health personnel, coverage of cured pulmonary tuberculosis, and measles vaccination.

The results from DEA shows us that North Sumatera, DKI Jakarta, West Java, East java, and South Sulawesi have the highest efficiency score. Those cities have 1 efficiency score of expenditure on healthcare. In the other hand Bangka Belitung Island has the lowest efficiency score among 34 provinces in Indonesia. Notwithstanding we infer, currently there are several provinces still cannot provide adequate healthcare because of inefficiency in budget spending such as Bangka Belitung Island, Gorontalo, and Maluku (3 lowest efficiency score).

Keywords: Efficiency, expenditure on healthcare, Indonesia healthcare, DEA. 


\section{Introduction}

Health inequality among all provinces in Indonesia becomes one of the main concern by government under Jokowi regime. Several measures have been attempted by the government to overcome this issue. Start from increasing health budget to $5 \%$ or raised $182 \%$ from previous state budget before Jokowi Regime as mandated in UU. Nevertheless bigger health budget were not depicted by better health quality in Indonesia, for example, number of malnutrition child in Indonesia up to $30 \%$ with WHO suggestion for ideal number is below 20\%. Another solution has been offered by the government is JKN (Jaminan Kesehatan Nasional) in collaboration with BPJS Kesehatan. This program is taking form of health insurance for poor or low purchasing power. The program is covering almost all health service in public hospital and private hospital from vaccination to surgery in order to increase health quality specifically until small / rural area. Unfortunately the program was not going well, huge aid from central government was not utilized efficiently by the local government / local health office, the fund was not well distributed among poor peoples. In addition, there are a lot of private hospital reject referred patient from local hospital / puskesmas because reimbursement system still not going effectively and complex bureaucracy has been an immense barrier for efficient aid from central government

Nowadays we don't talk anymore about amount of aid from the government, the amount is already big enough if only the local government can use it wisely and efficiently. Efficiency becomes of the reason why there is inequality in health quality among all provinces in Indonesia. Comparing HDI value each provinces, Papua has the smallest with 0,57point, in the other hand DKI Jakarta has the highest score with 0,789 point. Meanwhile Papua health deconcentration fund is up to 25 billion yet DKI Jakarta is only 9,5billion. 


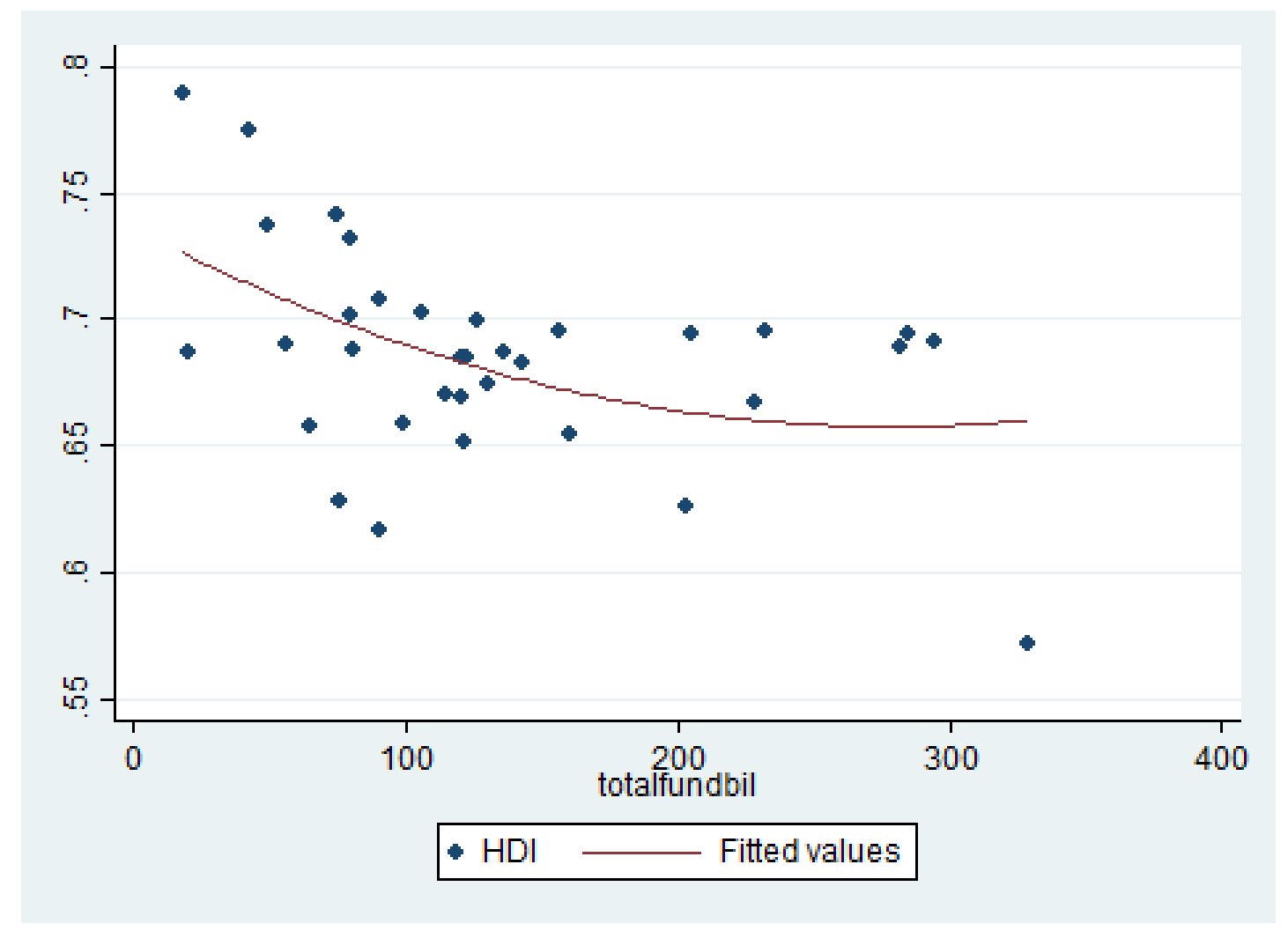

Graph 1 using Stata 13 by author

From graph 1 we can infer that in Indonesia provinces with high HDI value tend to get less aid from central government. Our graph makes trend that show us negative relationship between HDI and aid from central government regarding health quality health improvement.

Huge differences in health deconcentration fund show us how government try to equalize health quality between Capital City of Indonesia and the least advanced province, but still the gap cannot be avoided with "extra" fund. What government should do is fix the procedure of fund management and expenditure efficiency.

Efficiency issue is the main concern of this paper and will be discussed further with causes of inefficiency. Author tried to compare efficiency score all provinces in Indonesia and reveal factors behind it.

\section{Data}

Author used data from UNDP report for HDI Indonesia 2015 for all HDI value in all provinces in Indonesia. For Input, author used health deconcentration fund and health aid from central government that author got from Indonesia's health ministry annual report 2015 - Indonesia health profile 2015 -. For the output author used number of medication of 
malnutrition case, number of childbirth assisted by health personnel, number of treated diarrhea by health personnel, number of coverage cured pulmonary tuberculosis, and number of measles vaccination, also author got from Indonesia's health ministry annual report 2015. All of output that author used is the health indicator from health ministry of Indonesia. All of the inputs and outputs are considering all 34 provinces in Indonesia as follows:

\begin{tabular}{|c|l|}
\hline dmu & \multicolumn{1}{|c|}{ Province } \\
\hline 1 & Aceh \\
\hline 2 & Sumatera Utara \\
\hline 3 & Sumatera Barat \\
\hline 4 & Riau \\
\hline 5 & Jambi \\
\hline 6 & Sumatera Selatan \\
\hline 7 & Bengkulu \\
\hline 8 & Lampung \\
\hline 9 & Kepulauan Bangka Belitung \\
\hline 10 & Kepulauan Riau \\
\hline 11 & DKI Jakarta \\
\hline 12 & Jawa Barat \\
\hline 13 & Jawa Tengah \\
\hline 14 & D.I Yogyakarta \\
\hline 15 & Jawa Timur \\
\hline 16 & Banten \\
\hline 17 & Bali \\
\hline
\end{tabular}

\begin{tabular}{|l|l|}
\hline 18 & Nusa Tenggara Barat \\
\hline 19 & Nusa Tenggara Timur \\
\hline 20 & Kalimantan Barat \\
\hline 21 & Kalimantan Tengah \\
\hline 22 & Kalimantan Selatan \\
\hline 23 & Kalimantan Timur \\
\hline 24 & Kalimantan Utara \\
\hline 25 & Sulawesi Utara \\
\hline 26 & Sulawesi Tengah \\
\hline 27 & Sulawesi Selatan \\
\hline 28 & Sulawesi Tenggara \\
\hline 29 & Gorontalo \\
\hline 30 & Sulawesi Barat \\
\hline 31 & Maluku \\
\hline 32 & Maluku Utara \\
\hline 33 & Papua Barat \\
\hline 34 & Papua \\
\hline
\end{tabular}

\section{Methodology}

In finding efficiency score for all provinces in Indonesia, author used Stata13 for the regression, and used DEA (Data Envelopment Analysis) to reveal the efficiency score and variable return to scale based on input and output mentioned above. DEA is Stata-user command to find efficiency in production of a firm or a country. Using 1 year 2015 and option variable return to scale to analyze whether the province is increasing / decreasing / constant return to scale. Nonetheless author was using single stage regression and output oriented option. 


\section{Result and Discussion}

We measures efficiency using DEA with mentioned above inputs and outputs and rank all provinces based on their efficiency score. The results is showed as below (graph 2).

\begin{tabular}{|c|c|c|c|}
\hline VRS-OUTPUT & Oriented DEA & Efficiency & Results \\
\hline & rank & theta & \\
\hline dmux $=1$ & 28 & -182455 & \\
\hline dmax $=2$ & 1 & 1 & \\
\hline$d \ln x=3$ & 12 & -480576 & \\
\hline$d \ln x=4$ & 19 & .338629 & \\
\hline$d m a=5$ & 11 & .548149 & \\
\hline$d m x=6$ & 9 & .693712 & \\
\hline$d m x=7$ & 22 & .289651 & \\
\hline$d m x=8$ & 15 & .420213 & \\
\hline$d m u=9$ & 34 & .0988028 & \\
\hline$d \operatorname{lnu}=10$ & 23 & .269964 & \\
\hline$d m u=11$ & 1 & 1 & \\
\hline dmux $=12$ & 1 & 1 & \\
\hline$d m u=13$ & 7 & .830972 & \\
\hline dnnu $=14$ & 26 & .212716 & \\
\hline$d m u=15$ & 1 & 1 & \\
\hline$d \operatorname{mux}=16$ & 10 & .588988 & \\
\hline$d m u=17$ & 27 & -188411 & \\
\hline$d m u=18$ & 16 & .388898 & \\
\hline$d m u=19$ & 8 & .709182 & \\
\hline$d n u x=20$ & 21 & .293415 & \\
\hline$d m a x=21$ & 24 & .231088 & \\
\hline$d \cos =22$ & 17 & .37015 & \\
\hline$d n x=23$ & 20 & .308918 & \\
\hline$d m u=24$ & 18 & .359242 & \\
\hline$d m u=25$ & 14 & -446655 & \\
\hline dimu $=26$ & 6 & .846106 & \\
\hline$d m u x=27$ & 1 & 1 & \\
\hline$d m u=28$ & 25 & .219316 & \\
\hline$d m u=29$ & 32 & -125513 & \\
\hline$d m u=30$ & 29 & .160129 & \\
\hline$d m u=31$ & 33 & -117269 & \\
\hline$d m u=32$ & 31 & -129777 & \\
\hline dnnu $=33$ & 30 & -148031 & \\
\hline$d m u=34$ & 13 & .459379 & \\
\hline
\end{tabular}

Graph 2 using Stata 13 by author 
DMU (Decision-Making Units is our observation unit which are 34 provinces in Indonesia from Aceh to Papua. Using theta (efficiency score) as our based on ranking our DMUs. We consider 1 as efficient DMUs and below 1 is inefficient DMUs. The result is DKI Jakarta, North Sumatera, West Java, East Java, and South Sulawesi become the only efficient provinces in Indonesia, in the other hand, Bangka Belitung Island $(0,098)$, Gorontalo $(0,125)$, and Maluku $(0,117)$ become the least efficient provinces. We can infer from the graph 3, there are 4 provinces with decreasing return to scale production that are North Sumatera, South Sumatera, Central java, and Banten. Decreasing return to scale means every increasing in input factor will result in lower increases in output factors, for example, if we add up $20 \%$ from Banten's health budget, the output will increase less than $20 \%$. So as author has mention before. Now it does not matter about how big the budget is but how do they use it efficiently.

\begin{tabular}{|c|c|c|c|c|c|}
\hline \multicolumn{6}{|c|}{ VRS Frontier (-1:drs, 0 :crs, 1 :irs) } \\
\hline & CRS_TE & VRS_TE & NIRS_TE & SCALE & RTS \\
\hline dmu: 1 & 0.173092 & 0.182455 & 1.000000 & 0.948683 & 1.000000 \\
\hline dmu: 2 & 0.729957 & 1.000000 & 1.000000 & 0.729957 & -1.000000 \\
\hline dmu : 3 & 0.296474 & 0.480576 & 1.000000 & 0.616915 & 1.000000 \\
\hline dmu : 4 & 0.286513 & 0.338629 & 1.000000 & 0.846097 & 1.000000 \\
\hline dmu : 5 & 0.289348 & 0.548149 & 1.000000 & 0.527864 & 1.000000 \\
\hline dmu: 6 & 0.377487 & 0.693712 & 1.000000 & 0.544155 & -1.000000 \\
\hline dmu: 7 & 0.166417 & 0.289651 & 0.464806 & 0.574544 & 1.000000 \\
\hline dmu: 8 & 0.268329 & 0.420213 & 1.000000 & 0.638556 & 1.000000 \\
\hline$d m u: 9$ & 0.091317 & 0.098803 & 0.309603 & 0.924238 & 1.000000 \\
\hline $\mathrm{dmu}=10$ & 0.226991 & 0.269964 & 1.000000 & 0.840819 & 1.000000 \\
\hline dmu: 11 & 1.000000 & 1.000000 & 1.000000 & 1.000000 & 0.000000 \\
\hline dmu : 12 & 1.000000 & 1.000000 & 1.000000 & 1.000000 & 0.000000 \\
\hline dmu : 13 & 0.539350 & 0.830972 & 1.000000 & 0.649060 & -1.000000 \\
\hline dmu : 14 & 0.169702 & 0.212716 & 1.000000 & 0.797785 & 1.000000 \\
\hline dmu : 15 & 1.000000 & 1.000000 & 1.000000 & 1.000000 & 0.000000 \\
\hline$d m u: 16$ & 0.471293 & 0.588988 & 0.716171 & 0.800174 & 1.000000 \\
\hline dmu $: 17$ & 0.149195 & 0.188411 & 0.428492 & 0.791860 & 1.000000 \\
\hline dmu : 18 & 0.334303 & 0.388898 & 1.000000 & 0.859616 & 1.000000 \\
\hline$d m u: 19$ & 0.340864 & 0.709182 & 1.000000 & 0.480644 & -1.000000 \\
\hline dmu $: 20$ & 0.254362 & 0.293415 & 0.800061 & 0.866901 & 1.000000 \\
\hline dmu : 21 & 0.131095 & 0.231088 & 1.000000 & 0.567294 & 1.000000 \\
\hline$d m u: 22$ & 0.198088 & 0.370150 & 1.000000 & 0.535155 & 1.000000 \\
\hline dmu $: 23$ & 0.257706 & 0.308918 & 0.749749 & 0.834220 & 1.000000 \\
\hline dmu : 24 & 0.372309 & 0.359242 & 1.000000 & 1.036375 & 1.000000 \\
\hline$d m u: 25$ & 0.324781 & 0.446655 & 1.000000 & 0.727140 & 1.000000 \\
\hline$d m u: 26$ & 0.388702 & 0.846106 & 1.000000 & 0.459401 & 1.000000 \\
\hline $\mathrm{dmu}: 27$ & 1.000000 & 1.000000 & 1.000000 & 1.000000 & 0.000000 \\
\hline \multicolumn{6}{|c|}{${ }_{\mathrm{dm}}^{\mathrm{dm}}$ Graph 3 using Stata 13 by author } \\
\hline$d m u: 30$ & 0.160129 & 0.160129 & 1.000000 & 1.000000 & 0.000000 \\
\hline dmu : 31 & 0.115068 & 0.117269 & 1.000000 & 0.981232 & 1.000000 \\
\hline dmu: 32 & 0.102618 & 0.129777 & 0.433321 & 0.790725 & 1.000000 \\
\hline$d m u: 33$ & 0.108312 & 0.148031 & 1.000000 & 0.731679 & 1.000000 \\
\hline dmu : 34 & 0.394652 & 0.459379 & 1.000000 & 0.859100 & 1.000000 \\
\hline
\end{tabular}


There are several factors behind inefficiency production in some provinces in Indonesia. We found it at least 4 factors as main reason why local government cannot maximize the fund to increase their people's health quality.

1. Technological advancement

Technological advancement become the prior factor plays behind inefficiency. If we compare DKI Jakarta and Papua, of course it is obvious different in technology used by the local/public hospital. The most advanced technology is being used in DKI Jakarta and other biggest city in Indonesia. The better the technology will result it cheaper in cost of health services, for instance salary for nurse in Medan relatively cheaper than in Maluku, it's caused by the cost of living and accommodation in Maluku are hard to find and the quantity also is too low.

\section{Form of Financing}

Aid fund in big city such as DKI Jakarta mostly is used directly to help or financing cost health services for poor people, because all facilities are already provided by the hospital and the process is not too complex. Reimbursement system by the local hospital / private hospital with local government has been established well and clear although still had some trouble to be dissolved. However in Maluku the form of financing more concern on providing local hospital facilities and improving technologies and those expenditure are quite big and have no direct impact to local people health quality.

\section{Degree of Coverage}

Some local hospitals in DKI Jakarta are covering circumcision for free, nonetheless some local hospitals in Maluku are not covering such service because the hospitals do not have an adequate facility to perform the service, and not all hospital provides circumcision for free. Another example is vaccination, in big city like Bandung, local hospital provides free vaccination for measles because not hard to find the machine to produce the vaccine, yet in Papua there is no free service for vaccination around the provinces, only several local big hospital provide it, it is caused of not enough capable hospital producing the vaccine in low cost and fast. 
4. Administrative system

Complicated administrative system still becomes an unsolved problem in Indonesia's bureaucracy. Too many steps and levels to make one regulation, that is why all the fund in less developed provinces cannot be used well and have a fixing effect. Corruption also become endless struggle for Indonesia's government, any sector have a great opportunity to perform a corruption because of complex administrative system that makes persons can hide their manipulation. Big amount of aid is just a waste because of those people, the poor cannot get the advantage of their own tax and still to pay expensive health services.

\section{Conclusion}

After several analysis above we can conclude that the main problem in Indonesia's poor health quality is not about the size of the fund or aid from central government but it's more about how local government utilize and maximize the fund and the aid from central government in order to increase their people health quality and equality. Moreover, we found several factors that determine efficiency within a country in maximizing the fund and aid for healthcare services, there are technological advancement, form of financing, Degree of coverage, and administrative system. For Indonesia to improve their healthcare system, they should concern on expenditure efficiency and sources maximization. 


\section{References}

Dariatno Sihaloho, E. (2018). EFFICIENCY ANALYSIS OF LOCAL GOVERNMENT SPENDING OF REGENCIES AND CITIES IN WEST JAVA, 2001-2010. Review of Indonesian Economic and Business Studies (Vol. 6).

Medeiros, J., \& Schwierz, C. (2015, June). Efficiency estimates of health care systems. Economic Paper 549.

Pitriyan, P. (2013, July). Health Equality in Indonesia: Is it declining?

Utomo, B. (2011). Priorities and realities: addressing the rich-poor gap in health status and service access in Indonesia. International Journal for Equity in Health, 10-47. 